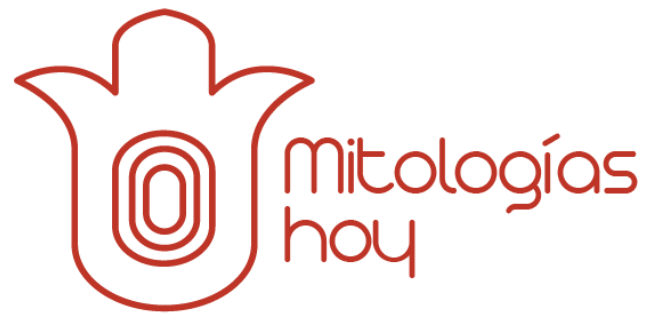

\title{
HERNÁN CORTÉS EN LA POESÍA MEXICANA DE LA SEGUNDA MITAD DEL SIGLO XX
}

\author{
Hernán Cortés in the Mexican Poetry of the Second Half \\ of the $20^{\text {th }}$ Century \\ Carmen Alemany Bay \\ Universitat d'Alacant (España) \\ carmen.alemany@ua.es \\ https://orcid.org/0000-0002-1405-9359
}

DOI: https://doi.org/10.5565/rev/mitologias.815

vol. 24 | noviembre 2021 | 19-32

Recibido: 26/07/2021 | Aceptado: 17/09/2021

\section{Resumen:}

A más de quinientos años de la conquista de México, la presencia de Hernán Cortés (14851547) en la poesía mexicana es más bien escasa; sin embargo, existen muestras relevantes que evidencian el interés que este personaje suscitó y sigue suscitando. Poetas señeros de la segunda mitad del siglo pasado, como lo fueron Rubén Bonifaz Nuño (1923-2013), José Emilio Pacheco (1939-2014) y Homero Aridjis (1940), acuden a la figura del conquistador en un afán de reconstruir desde nuevas perspectivas la historia del conquistador. En la década de los noventa, Kyra Galván (1956) plantea otro tipo de acercamiento a la figura de Cortés que tendrá su resonancia en la poesía posterior, la que sobre él se escribirá en el nuevo siglo.

\section{Palabras clave}

Hernán Cortés, Rubén Bonifaz Nuño, José Emilio Pacheco, Homero Aridjis, Kyra Galván. 


\section{Abstract}

It has been more than five hundred years since Mexico, was conquered and the presence of Hernán Cortés (1485-1547) in the Mexican poetry is rather scarce; nevertheless, there are relevant examples showing the interest that this person aroused in the past and also in the present time. Outstanding poets of the second half of the previous century, such as Rubén Bonifaz Nuño (1923-2013), José Emilio Pacheco (1939-2014) and Homero Aridjis (1940), use the figure of the conqueror in an attempt to rebuild from new points of view the history of the conquerors. In the 90s, Kyra Galván (1956) proposes other approach to the figure of Cortés that will have its repercussion in later poetry, the one that will be written in the new century.

\section{Keywords}

Hernán Cortés, Rubén Bonifaz Nuño, José Emilio Pacheco, Homero Aridjis, Kyra Galván.

La sombra de Hernán Cortés sigue siendo alargada a pesar de la moderada presencia de la figura del conquistador español en la poesía mexicana a lo largo del siglo XX y las dos décadas del XXI; a diferencia de otros géneros en los que este personaje ha tenido cierta continuidad. Su nombre sigue siendo símbolo de violencia y su elipsis — en lo que concierne a lo poético— es evidente: no se le nombra, no se le invoca para no desatar más odio o dolor, convirtiéndose en una figura casi espectral. En cualquier caso, cuando los poetas lo invocan revelan un mundo que ya no existe; los restos de la historia oficial se fusiona con la imaginación del versificador y es fundamentalmente a través de esta que se reconstruye el discurso, un discurso que necesariamente se mueve en estereotipos.

\section{Sobre la poesía histórica latinoamericana: años 50 y 60}

Fue en la década de los sesenta y comienzos de los setenta cuando dos poetas señeros encauzan parte de su poética a refrendar los hechos históricos ocurridos en los primeros años de la conquista. Tanto Rubén Bonifaz Nuño como José Emilio Pacheco entran en esta dinámica que se une a la que están ofreciendo otros poetas del continente americano. Estamos ante un tiempo de fuerte emergencia social y política — referente ineludible es la Revolución cubana (1959)—, y de una clara consciencia latinoamericanista e identitaria en la que a la vez escritores e intelectuales rescatan aquellos iconos nacionales que sirven asimismo para configurar un mapa que permita la asunción de lo latinoamericano. La literatura se erige como un discurso mediante el cual se pueden construir las narraciones de identidad, pero también de formación y de testimonio. Se hacen eco de la idea del encuentro de culturas con el fin de reelaborar el choque de miradas y preponderar la visión del otro.

En este contexto el verso se constituye como arma subversiva para la recuperación crítica y la reinterpretación del pasado; una poesía de corte histórico que oscila entre el realismo comprometido, dominante a partir de mediados de los años cincuenta, y que se prolonga con el compromiso de los poetas coloquiales de los sesenta y parte de los setenta. El pistoletazo de salida lo dio el chileno Pablo Neruda (1904-1973) con el Canto general (1950): "un conjunto orgánico de poemas históricos”, en palabras de 
Robin Lefere (2014: 60), en el que se desarrolla una poética que cuestiona la visión colonizadora occidental, se reestructura el poema épico como género y las simbologías y las metaforizaciones sirven para enfatizar la esencia de lo americano, amén de las voces de los vencidos. Desde México será crucial la publicación de Aguila o sol, en 1951, de Octavio Paz (1914-1998). Por su parte, un discípulo directo de Neruda, el ecuatoriano Jorge Enrique Adoum (1926-2009), continuará esa trayectoria con Los cuadernos de la tierra compuesta por cuatro poemarios, publicados a lo largo de casi una década (el primero data de 1952 y el último de 1961), con el fin de poetizar la historia colectiva de su país; como también hizo su compatriota César Dávila Andrade (1918-1967). En esta misma andadura estarán el peruano Antonio Cisneros con Comentarios reales (1964); el nicaragüense Ernesto Cardenal (1925-2020) se sumará a esta cadena de reivindicación y reescritura de lo latinoamericano en El estrecho dudoso (1967), y también el venezolano Juan Liscano (1915-2001) (Alemany, 2017).

Desde lo poético se mantiene la idea de que para construir una identidad fuerte y duradera hay que denunciar, sin paliativos, lo que desde la crónica oficial se edulcoró. Estos poetas se ven en la necesidad de evidenciar lo ocurrido en los siglos pasados: que la conquista española supuso una fractura de la historia, la sustitución de una lengua por otra, de unas religiones por otra, del traslado de una forma de vivir y de pensar a otra. Por tanto, reescribir la historia era una necesidad para configurar la verdadera identidad sin la cual, inevitablemente, se caía en una desmemoria abocada a repetir los errores. Estamos ante poemarios y composiciones que tratan de acercarse de una manera comprensiva, y a la vez subversiva, a la llamada visión de los vencidos con el que titulara Miguel León-Portilla uno de sus más afamados libros cuya primera edición data de 1959; fecha que enfatiza más la idea de que aquellos años fueron cruciales para rescatar y alcanzar otras visiones de lo americano.

Desde la instancia discursiva, estos poetas abogarán por una perspectiva en la que el entrecruzamiento de diferentes voces o máscaras líricas van a permitir un distanciamiento crítico que otorgará cierta apariencia de objetividad. Como ha observado Miguel Ángel Gómez Soriano,

Gracias a este recurso, más teatral o narrativo que poético (como indicador, será habitual la presencia de parlamentos entrecomillados intercalados en los poemas), se incorporan al discurso diferentes puntos de vista: desde uno más externo (a modo de narrador lírico), hasta una perspectiva coral que podemos asociar al pueblo, pasando por la suplantación de diferentes personajes de la historia. (2019: 262)

Asimismo, y siguiendo al citado crítico, se ofrece una reescritura del pasado acorde con sus propios valores y las barreras entre pasado y presente se difuminan, la materia histórica se reinventa como mensaje para el presente histórico. En no pocas ocasiones no interesan los nombres o los datos exactos sino el trasfondo que estos tienen (Gómez, 2019: 262).

\section{Hernán Cortés en la poesía de Rubén Bonifaz Nuño, José Emilio Pacheco y Homero Aridjis}

Conocida es la actitud descolonizadora de Rubén Bonifaz Nuño. En no pocas ocasiones se refirió a aquel episodio reflejado en "La Tercera Carta de Relación dirigida a Carlos V", que data de 1522, cuando Cortés dijo: "Quiero hablar con uno de sus grandes señores", y como decía Nuño: "uno de los nuestros responde: «Puedes hablar con quien quieras. Todos somos grandes señores»" (Campos, 2000). Y como añadiera en su texto "La descolonización de México": "que a eso tienda nuestra educación, que eso nos digan los libros de texto; que se nos enseñe que nuestra visión del mundo no ha de ser la visión de los vencidos, sino la visión de los grandes señores" (1988: 25). A lo que se suma lo que destacó en una entrevista que le hiciera Marco Antonio Campos y que se publicó en La Jornada Semanal: "Por eso he 
buscado que mis trabajos se introduzcan en las escuelas y en las casas. Que los niños antes de oír las grandezas de Inglaterra y de España, aprendan a conocer nuestra grandeza antigua y la vuelvan presente" (2000), para reseñar a continuación lo escrito en líneas anteriores.

Otro momento reivindicativo fue cuando en 1990 se quiso erigir un monumento dedicado al conquistador, la respuesta de nuestro poeta fue contundente; asimismo relevante es su esfuerzo por "descolonizar" a México mediante el análisis de las imágenes prehispánicas como fuente primaria, tal como podemos comprobar en Imagen de Tláloc: hipótesis iconográfica y textual (1986), cuyas páginas abrían el debate en torno al monumento conocido como Coatlicue.

Si entramos en harinas poéticas, no cabe duda de que la obra crucial para los intereses que estamos tratando es Fuego de pobres, publicada en 1961, y que fue incluida en De otro modo lo mismo. El poemario contiene al menos cuatro composiciones en las que de manera indirecta resurge la imagen de Hernán Cortés, la elipsis de la que hablábamos se vuelve aquí sustancial: por la acción del conquistador se produjeron los hechos conocidos y es el momento de ofrecernos, como aquí lo hace el poeta, la visión del otro. Nos referimos a "Como rumor de muchedumbre" (poema 10), "Noche mortal y combatiente, niebla" (poema 19), "¿Fue el penacho del grito, fue la hoja" (poema 32) y "Hervor de calles; desembocadura" (poema 33). En el 10 y en el 33 refleja la ciudad en los momentos de la toma por parte del conquistador Cortés. En el primero de ellos, la voz del sujeto poético se traslada al pasado para rememorar en la primera estrofa el hecho que acabamos de referenciar: "Como rumor de muchedumbre, o ruido / de torrentes huyendo, se construye, / sobre el silencio del durmiente, / el silencio de afuera: el que levantan / los dispuestos es cerco, los que miran / despertando sus armas en tu contra" (1996: 245). El poeta se convierte en portavoz de la ciudad ultrajada que él, por encima de todo, quiere preservar contra la insidia; y así rememora aquel pasado que rechaza para el tiempo presente:

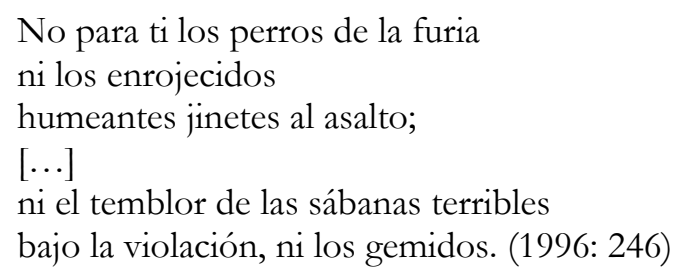

En "Hervor de calles; desembocadura" volverá sobre la misma temática de la Ciudad de México acuciada por la masacre; aunque en realidad, y muy de acuerdo con aquella década de pensamiento utópico, se dirige a un tú solidario para que no se vuelva a recaer en la dominación, en una nueva colonización. De ahí esos versos que dan comienzo al poema: "Hervor de calles; desembocadura / de pábulos ardiendo, en la caldera / sediciosa del mísero" (1996: 278). Las referencias a los gritos, al humo, a los abatidos dan paso al verso "Nace la gloria para ti, mi hermano" (1996: 278) con el fin de solidarizarse con los pobres, los vecinos, los inválidos, los desterrados, los hambrientos, las "mujeres para siempre olvidadas" (1996: 278), y augurar una nueva época en la que

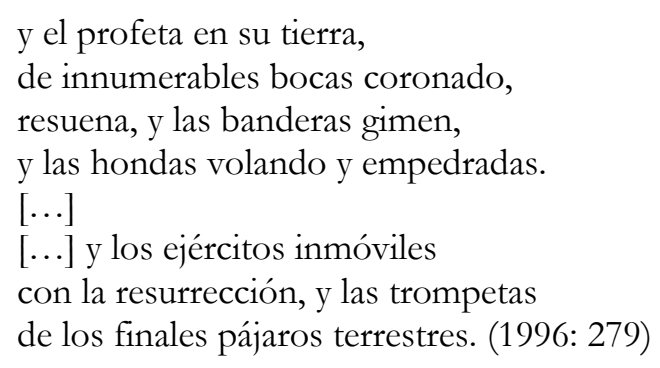

En el poema 19, "Noche mortal y combatiente, niebla", se vuelve a rememorar aquella noche de la ignominia, noche en la que el guerrero tendrá "una muerte de lujo" y "sombra y ceniza cubren su cabeza" (1996: 259). Si al lector le surge alguna duda de a qué momento histórico se está refiriendo el 
sujeto poético esta queda zanjada por los versos que cierran la composición: "Hasta la grieta horizontal del alba, / y la cadera rota y el bautismo" (1996: 260). En la misma tonalidad se expresa Rubén Bonifaz Nuño en la composición 32, cuyos versos inaugurales se refieren al momento del combate, y el sujeto poético así se interroga: “¿Fue el penacho del grito, fue la hoja / cabelluda del grito, fue el ahogo?” (1996: 276); sin embargo, se da un giro notable en el poema, una vuelta en la que el gozo parece sustituir el fragor brutal de la batalla para redondear la composición con vocablos que inspiran claras referencias positivas: "como la luz ecuestre del lagarto / en la roca de espuma, como el vientre / del fuego original, como naciendo" (1996: 277).

La figura de Cortés sobrevuela los versos, la elipsis es la referencia y sus versos se instalan una y otra vez en la noche de la vergüenza. A su vez la voz poética juega entre el pasado y el presente en un afán de que la historia no vuelva a repetirse, pero sobre todo resaltar la infamia que significó aquel momento histórico. ${ }^{1}$

José Emilio Pacheco ha sido uno de los autores que desde la poética coloquial más han indagado sobre el descubrimiento y la conquista desde el distanciamiento irónico que le caracteriza. Como afirmamos hace unos años, este

no es un tema prioritario en su poética, pero sí necesario porque esta temática ayudó al autor en sus primeros años de poeta a configurar la complejidad del mundo mexicano, tan presente en todos sus versos, y a ensayar la importancia que la intertextualidad tendrá siempre en su obra. (Alemany, 2004: 5)

No son pocas las composiciones de contenido americano, centradas en la recuperación del pasado, que fueron incluidas en No me preguntes cómo pasa el tiempo (1968) e Islas a la deriva (1975), por citar los ejemplos más notables. En la segunda parte, de las cinco que componen el segundo de los poemarios aludidos, denominada por el autor "Antigüedades mexicanas", aborda distintos momentos de la historia de México desde una perspectiva irónico-crítica que comienza con el descubrimiento, avanza hasta la colonia y llega al presente. Para nuestros intereses, nos centramos en concreto en las composiciones "Doña Marina” y "Temilotzin de Tlatelolco". En ninguno de los dos poemas Hernán Cortés es figura central; acorde con la época y los intereses ya expuestos Pacheco les da voz a los otros.

En el segundo de ellos, "Temiltotzin de Tlatelolco", versifica la vida de este poeta de finales del siglo XV quien luchó contra los españoles en la defensa de Tenochtitlán, junto a Cuauhtémoc, quien ya preso de Cortés desapareció, y aquí entra la imaginación de poeta: "se arrojó / a las olas del mar y nadie sabe/ si acabaron con él los grandes peces / o si alcanzó la orilla" (2010: 171-172). No olvidemos que este personaje fue figura indígena central en los Cantares mexicanos, aunque periférica en la historia tradicional de la conquista. Su figura es descrita en pocas líneas a través de una estructura épico-narrativa que trabaja con la sonoridad del náhuatl (con términos como "calmécac", "tlacatécatl", "Tlatelolco", "tlatoani"), o con imágenes que remiten a los citados Cantares mexicanos, tal como señala Valeria Añón (2008). Así dice el poema:

Temilotzin nacido en Tlatelolco

se hizo poeta en el calmécac

y dejó escrito:

"Dios me envió a la tierra

para hacer la amistad entre los hombres."

\footnotetext{
${ }^{1}$ El mismo Bonifaz Nuño, poco antes de la publicación de Fuego de pobres escribió, en 1958, una extensa composición titulada "Canto llano a Simón Bolívar", que fue incluida en el libro De otro modo lo mismo, de 1979. Si sacamos a colación este texto es porque en él Nuño rememoraba la historia y la voz del porvenir en la figura de Simón Bolívar. En un afán de panhispanismo, desde el pensamiento martiano, México se integra con aquellas naciones que configurarán una América Latina hermana, fuerte y poderosa, muy al son de los discursos intelectuales de la época, de ahí el final del texto: “Aquí estamos, esperando en la noche. / Naciones, hombres, mujeres. / Y tú, México; patria, mi patria” (1979: 220).
} 


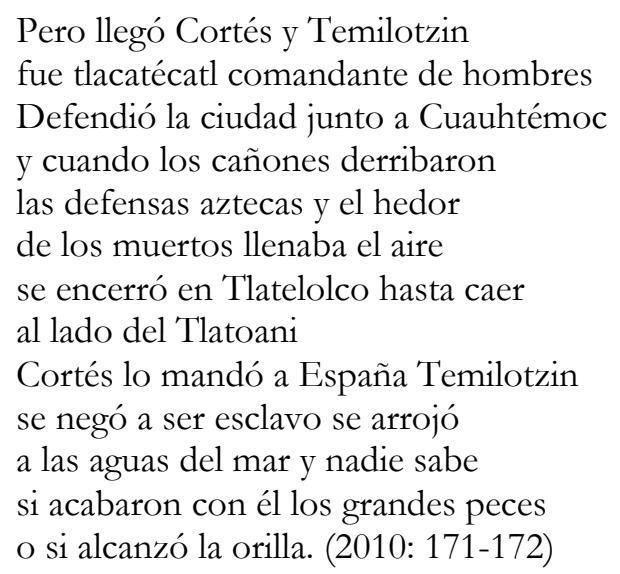

Acorde con su tiempo, Pacheco sigue las líneas genéricas de la historia oficial para sumergirse en un discurso dirigido a reseñar implícitamente la maldad del conquistador. Para resaltar la objetividad incluye parte de su discurso entre comillas, lo que está escrito, pues solo lo que está escrito prevalece y se convierte en historia. Como señalara Añón:

El poema cierra con una apelación que contribuye a crear una imagen mítica. La estructura de versos endecasílabos y un remate en heptasílabo marca la elección preferencial del sujeto lírico que funciona aquí como un narrador: este elige los resquicios de una historia tantas veces contada, aquellos que le permiten cimentar una elegía, una figura épica como cimiento de la identidad mexicana posterior. (2008: 7)

Otro de los personajes más conocidos de la historia del México colonial fue Doña Marina, la Malinche. En los versos de Pacheco ella no será la protagonista, sino Jerónimo de Aguilar y Gonzalo Guerrero. Sabemos de la historia de ambos, y que nuestro poeta la resume en unos cuantos versos partiendo de lo relatado en la Historia verdadera de la conquista de Nueva España (1632) de Bernal Díaz del Castillo, a partir del capítulo XXVII. Después de un naufragio ambos vivieron con los mayas, Gonzalo Guerrero tuvo hijos mestizos y renunció a volver con los españoles, con Cortés, e incluso luchó contra ellos; en cambio, Aguilar huyó de todo contacto con los indígenas y regresó con el conquistador español convirtiéndose - gracias a sus conocimientos de la lengua indígena- en el traductor de Cortés. Sin embargo, desde el punto de vista del poeta mexicano, lo que en realidad hicieron estos dos personajes fue potenciar "el mestizaje, / el enredo llamado México, la pugna / de hispanismo e indigenismo" (2010: 170). En la composición, Cortés es el incentivador de lo ocurrido en la historia de México, pero no interesa su historia sino la de aquellos que marcaron otro destino. La elipsis sobre la figura de Cortés es evidente; no se alude al personaje sino a aquellos que lo han rodeado y que han perfilado, como hemos subrayado, otros rumbos más cercanos a la esencia, a la idiosincrasia de lo americano.

No muy lejano de las intenciones suscritas por los citados autores está la de Homero Aridjis. Como ha apuntado Víctor Manuel Sanchis, "Los mismos temas que aparecían en Pacheco, eternamente mexicanos, como la desolación, la muerte o el tempus fugit, hilarán las obras de una poesía que volverá a preocuparse por el aspecto formal, fijando su atención en temas clásicos, bebiendo también de la retórica comunicante" (2015: 156). Pero en el caso del autor michoacano, existe un corpus mayor de poemas, amén de un interés por el tema que se desplaza asimismo hacia otros géneros. En 1988 publicó la novela Memorias del Nuevo Mundo, la continuación de 1492. Vida y tiempos de Juan Caberón de Castilla (1985); ambas forman parte de un proyecto de nuestro autor en el que indaga respectivamente los precedentes del tema de la conquista y descubrimiento de América. Y es en Memorias del Nuevo Mundo donde Hernán Cortés se alza como protagonista para relatarnos los sucesos de la conquista de México-Tenochtitlán. Como señaló Aníbal Salazar Anglada, "desde la publicación en 1975 del poemario Quemar las naves, el tema del descubrimiento y conquista de América, con el consecuente choque mental entre el viejo y el nuevo mundo, va a ser una constante en la obra de Aridjis, sea en la poesía, el teatro o la novela" (2019: 152). 
Y es precisamente en este libro, Quemar las naves (1975), en el que se incluye el poema que abre el corpus cortesiano en la obra poética de Aridjis con la composición de título homónimo. Le seguirán "Jinetes", que forma parte de Vivir para ver (1977); y la mayor parte de poemas sobre Cortés se incluirán en Nueva expulsión del Paraíso (1990): "Desde lo alto del templo Moctezuma muestra a Cortés su imperio", "Hernán Cortés navega", "Antigua, Veracruz", "Casa de Hernán Cortés en Antigua, Veracruz", "Conquistador anónimo" y "Dos poemas lascasianos".

"Quemar las naves" nos remite a una de las muchas leyendas en torno a Cortés. Y acudiendo de nuevo a las palabras de Aníbal Salazar, es a partir de este libro cuando por primera vez "irrumpen como temas poéticos la empresa de Cortés (el título del poemario alude, de hecho, a un conocido pasaje atribuido al conquistador extremeño) y el mundo de los mexicas, del que fue señor y dueño el tlatoani Moctezuma" (2020: 85). El pasaje hace referencia a que el conquistador quemó las naves al llegar a las costas de México para que los que iban con él no pudieran regresar a España. ${ }^{2}$ Aquí el poeta michoacano toma este hecho para jugar con la frase hecha "quemar las naves", y es la voz de Cortés la que nos habla para indicarnos que es el momento de dejar atrás lo vivido y enfrentarse, con perspectivas inéditas, lo que la nueva tierra les ofrece. Reveladores en este sentido son los tres versos que cierran el poema: "para que sobre lo quemado / caminemos sin miedo / en el aquí y ahora" (2002: 320); tras haber escrito en versos anteriores que "no piensen que es posible / volver a ser lo que eran / en el país perdido" (2002: 320). Que no caiga en saco roto el verso "para que sobre lo quemado", que es indicativo de las acciones que los españoles hicieran cuando llegaran a aquellas tierras y que nos remite a uno de los poemas de Bonifaz Nuño.

Dos años después sale a la luz Vivir para ver (1977), y desde otra perspectiva, nos remite nuevamente a la figura del conquistador en "Jinetes", donde podemos percibir a "los conquistadores españoles como seres fantasmales atravesar las costuras del tiempo y cruzar a galope tendido por el presente" (Salazar, 2020: 87):

Hernán Cortés en su caballo zaino

Pedro de Alvarado en su yegua alazana

Francisco de Montejo en su alazán tostado

llegaron un día al mar

y desde entonces por los llanos polvorientos

a través de vivos y muertos

sin mañana y sin noche

no dejan de galopar hacia la luz. (2002: 390)

Retomamos las palabras de Salazar, la de los "seres fantasmales" que recorren "las costuras del tiempo" porque enlaza con otra idea interesante que plantea el citado crítico: "la idea de que los muertos — los indios mexicas, los conquistadores, los héroes de la Revolución... - no acaban de morirse y atraviesan el tiempo y siguen instalados en la realidad" (Salazar, 2019: 153). ${ }^{3}$ Estos tres personajes

\footnotetext{
2 Tal como advierte Aníbal Salazar: "La leyenda proviene, al parecer, del historiador novohispano Juan Suárez Peralta «el Viejo», que vivió en el siglo XVI y escribió, entre otras obras, un Tratado del descubrimiento de las Indias y su conquista, centrado en el reino de la Nueva España. El pasaje aparece asimismo descrito en otras crónicas de Indias (Francisco López de Gómara, Antonio de Solís), aunque en ellas lo que se dice es que Cortés mandó barrenar las naves, es decir, agujerearlas para que se hundiesen" (2019: 128).

${ }^{3}$ En este mismo artículo se abunda en las siguientes ideas, una que hace referencia al poema en cuestión: "En otro poema, «Jinetes», dedicado a los conquistadores de México-Tenochtitlán, Aridjis ensaya una fantasmagoría que luego extenderá a los héroes de la Revolución mexicana. Los muertos siguen en pie, atraviesan el tiempo" (2019: 121); y otra sobre la presencia de esos personajes del pasado que superan las líneas del tiempo: "Más adelante volveremos a estas figuras espectrales (dioses, guerreros, conquistadores, revolucionarios) que, como se verá, en la cosmovisión aridjisiana siguen habitando el México del siglo XXI, pues en este tipo de imágenes oníricas subyace la interpretación profunda que articula el autor del statu quo social y político de México, por cierto, nada optimista, cabe avanzar" (2019: 121-122).
} 
históricos, como se sabe, protagonizaron la conquista de México, los dos últimos en calidad de adelantados. Estableciendo enlaces con el poema anterior, hay una mención al mar, que queda atrás (pasado), y se insiste nuevamente en la idea del avance, del futuro; pero sí es verdad que conformando ya de forma explícita la idea apuntada por Salazar.

Tendrán que pasar trece años hasta que vuelva a aparecer en la figura de Cortés en la poesía de Aridjis en Nueva expulsión del Paraíso. Lógicamente ha pasado un lapso de tiempo considerable, el autor ya ha publicado la citada novela Memorias del Nuevo Mundo y ha habido una amplia producción, sobre todo narrativa, en torno a personajes históricos y al revisionismo histórico que tuvo como epicentro el $\mathrm{V}$ Centenario. Y quizás esta sería la explicación de la presencia de lo histórico en la poesía del michoacano.

Comenzaremos con el poema "Desde lo alto del templo Moctezuma muestra a Cortés su imperio". En los nueve versos que lo componen, el sujeto poético, Moctezuma, señor de MéxicoTenochtitlán, explica a Cortés que, como se anuncia en el primer verso: "Lo que miran tus ojos es nuestro" (2002: 493). Homero Aridjis recrea una conocida escena histórica e intenta, a través de este monólogo, mostrar la generosidad, la magnificencia, en definitiva, del que fuera dueño y señor de aquellas tierras: todo lo comparte con el extranjero, con el recién llegado. No ceja el tlatoani en explicar las bondades de su gente para con los otros, pero también saca a colación los ritos sangrientos por los que eran conocidos los aztecas; de ahí que termine la composición con los siguientes versos: "y para alumbrar nuestro día / con un cuchillo negro sacamos luz / del corazón de nuestros enemigos" (2002: 493). ${ }^{5}$

En "Hernán Cortés navega", el escritor michoacano -a través de una composición formada por seis estrofas de dos versos- nos sitúa el futuro conquistador de México en un barco en La Habana y "al timón Alaminos sueña" (2002: 604), en clara referencia a la historia de las crónicas. Recordemos que el marino español Antón de Alaminos acompañó en 1519 a Hernán Cortés en aquel viaje que culminó con la Conquista de México. Esa apacible espera del barco desemboca es un final clarividente: "y México se vislumbra / en un sueño de oro" (2002: 604), aludiendo sutilmente a la sonada avaricia de Cortés.

Sabemos que un enclave importantísimo para nuestro protagonista fue la ciudad de Antigua, en el estado de Veracruz, donde Hernán Cortes se asentó con los suyos en 1525, y levantaron un poblado y un puerto en las orillas del río Huitzilapan. Allí se conserva una casa, típica de la colonia, que, según dicen, fue la casa de Hernán Cortés. A esta población le dedica dos poemas de índole diversa: "Antigua, Veracruz" y "Casa de Hernán Cortés en Antigua, Veracruz". En el primero de ellos, compuesto por cuatro estrofas de dos versos, vuelve a las referencias históricas y, en este caso, establece enlaces con su obra anterior tal como veremos a continuación. Se recuerda, en el verso primero, que es "Aquí, de donde Cortés partió hacia México" (2002: 604) para aludir a continuación al "olvido" y la "desmemoria". En clave paralelística respecto al primer verso, en el quinto escribe: "Aquí, donde Cortés quemó sus naves", que enlazaría con el primer poema que sobre el conquistador escribió para cerrar la composición con un juego de palabras derivativo que nos remite no ya solo a lo histórico sino también a lo personal; un paso de lo uno a lo otro: "bien puede decirse // que el conquistador de México / nunca se conquistó a sí mismo" (2002: 604). "Casa de Hernán Cortés en Antigua, Veracruz" reza así:

\footnotetext{
${ }^{4}$ Esta composición pertenece al libro Imágenes para el fin del milenio (1986), aunque se publicó en 1990, conjuntamente con Nueva expulsión del Paraíso. Tanto en este caso como en el de los poemas que pertenecen a este libro los citamos por el volumen de su poesía reunida que en 2002 se publicó bajo el nombre de Ojos de otro mirar. Poesía, 1960-2001.

${ }^{5}$ Víctor Manuel Sanchis Amat ha hecho la siguiente lectura de este poema: “Aridjis se vale además de la retórica dramática para presentar una escena en la que desde lo alto del templo Moctezuma muestra a Cortés su imperio. El monólogo en primera persona enfrenta a Moctezuma con el capitán español ante la grandeza del Imperio azteca («ciudades y nubes mujeres y piedras / coyotes y víboras ahuehuetes y águilas») y le advierte de sus costumbres («nuestros hombres atraviesan las aguas / y nuestros dioses recorren la noche / y para alumbrar nuestro día / con un cuchillo negro sacamos la luz / del corazón de nuestros enemigos»). El dramatismo de la escena provoca a un lector que conoce el desenlace de la historia: fueron los hombres de Cortés los que sacaron la luz acuchillando los corazones de sus enemigos” (2015: 159).
} 
Dicen que la vida brota

en los lugares más inapropiados

y la Naturaleza hace crecer sus árboles

en las habitaciones derrumbadas,

como si la historia no quisiera irse

del esqueleto y del escombro,

mientras la lluvia entra

por las paredes sin puerta del olvido. (2002: 605)

El "olvido" con el que cierra el poema va siendo una palabra clave que había transitado también en la composición anterior. Sin embargo, aquí el poeta ha prescindido de lo histórico para internarse en el ámbito personal como leemos en el poema recién comentado. La casa, la de Cortés, será la excusa para reflexionar sobre el abandono; pero fundamentalmente sobre la pervivencia de la historia ("como si la historia no quisiera irse"), y ese olvido del que hablábamos al comienzo de este párrafo "sin puerta": "El poema toma como motivo la fronda espesa de árboles que, con el tiempo, ha ido rodeando y penetrando el recinto conocido como «Casa de Hernán Cortés»" (Salazar, 2018: 268).

El penúltimo de los poemas de temática cortesiana de este libro es el "Conquistador anónimo", que no debe confundirse con el poema titulado "Un conquistador anónimo recuerda su paso por las tierras nuevas", perteneciente a un libro de poemas anterior, Imágenes para el fin del milenio (1986); libro en el que hay un numeroso corpus de poemas que reflexionan sobre el pasado histórico. En este la figura de Cortés no aparece, pero comparte con aquel, en algún momento, la mimetización con el indio y la idea, presente en algunos de los poemas que hemos analizado, de que los muertos atraviesan el tiempo y siguen de otro modo en el presente, en la realidad.

Rompiendo con el esquema formal de las composiciones que sobre este tema hemos visto hasta ahora, en esta ocasión Aridjis opta por el verso largo, casi narrativo, en el que desde la primera persona ese "conquistador anónimo" nos relata el olvido de su persona por parte de los cronistas para reivindicar su presencia en la conquista de México, su conocimiento del "Nuevo Mundo" y que "Hernán Cortés, compañero de historias / me confió el orden de las batallas / y tendí emboscadas a los enemigos y a los amigos." (2002: 605). Es a partir de esos momentos cuando el discurso poético detalla aquellas costumbres y prácticas de los conquistadores: el obispo de México quiso casarle con una indígena, quemó tempos y asesinó mexicanos y ya viejo construyó iglesias y se avino a las costumbres del lugar; acciones que sirven para mostrar, asimismo, la brutalidad de los aztecas: "Como un azteca comí carne y bebí sangre de esclavos / en mesas de piedras y en altares al dios zurdo" (2002: 606). Y este es el único poema del corpus en el que se establece la comparativa entre el salvajismo atribuido a los aztecas similar al de su lugar de procedencia, España: "Pero quien de entre nosotros que presencia ahora sacrificios / humanos / no oyó en las plazas de España aullar a los herejes / condenados al fuego en nombre de la Iglesia." (2002: 606); para sentenciar que no importa ser materia de olvido por parte de los cronistas, pues, como reza el último verso: "Ellos serán un día olvidado" (2002: 605). Más allá del nombre que se halle detrás, hay un intento - creemos- por parte del autor de mostrar las acciones y vivencias que los conquistadores llevaron a cabo.

De los "Dos poemas lascasianos", es en el segundo, "Conquistadores todos" (2002: 607), en el que Cortés es mencionado; el primero, "Tristes tiranos, capitanes de la muerte", tiene como protagonista al padre Las Casas. Nos serviremos de las explicaciones que Aníbal Salazar ha vertido sobre aquel por considerar su acierto y porque vuelve a incidir en esa idea de la que hablábamos en líneas anteriores, a propósito de la composición "Jinetes", con lo que se afianza la elaboración de un proyecto sobre lo histórico en la obra de Aridjis y en la que Hernán Cortés es pieza fundamental:

En el segundo de los "poemas lascasianos", titulado "Conquistadores todos", Aridjis plasma, una vez más, la idea de que las sombras de quienes emprendieron la conquista y aniquilaron a los indígenas 
siguen, metamorfoseados, morando en México, con otros rostros, otros cuerpos. De modo que "Hernán Cortés, Pedro de Alvarado, / Nuño de Guzmán, Francisco Pizarro, / conquistadores todos ... / siguen recorriendo con otros nombres/ estas tierras desventuradas". Y prosiguen, entonces, esparciendo la violencia por los cuatro costados de un país que se desangra. Sin embargo, desde la interpretación que hace Aridjis de la genealogía de la violencia y el poder corrupto en México, estos no darían comienzo con la llegada del hombre blanco, lo que combate la idea, prejuiciosa, de que todos los males de Latinoamérica comienzan en 1492, caldo de cultivo de una hispanofobia aún vigente, especialmente en un país como México (combatir este hecho, desde luego, no exime de poner en cuestión los desmanes cometidos en nombre de la Corona española durante periodo de conquista y colonización y sus nefastas consecuencias. Al entender del escritor michoacano, la violencia se inicia mucho más atrás, en los ritos sangrientos de las comunidades indígenas, en el trato cruento que el Imperio azteca da a las tribus enemigas, justificando tales actos con la invención de dioses crueles. Esta reflexión, que va madurando en Aridjis a lo largo del tiempo, se hace palmaria en Diario de sueños (2011). (Salazar, 2019: 155)

Tras el análisis de este corpus creemos que queda patente los diversos acercamientos al personaje de Cortés. Mientras Bonifaz Nuño y Pacheco se remiten a los hechos contados desde las crónicas, pero prescindiendo de la mención directa al conquistador extremeño; Aridjis entra plenamente en una poética en la que Cortés es centro de sus versos, descartando de este modo la elipsis que era evidente en la poética de los años sesenta. La del michoacano pertenece a otro tipo de proyecto que guarda relación directa con sus obras narrativas fundamentalmente, está en su ánimo recrear la historia, la épica desde la poesía.

\section{Nuevas formas poéticas para abordar a Hernán Cortés}

Aunque en el primer año de los noventa Aridjis publicó Nueva expulsión del Paraíso (1990), obra en la que, como hemos visto, hay un tratamiento amplio de nuestro personaje histórico, la forma de abordarlo guarda estrechas similitudes con lo realizado en los setenta y una manera de acometer lo poético propio de aquellas décadas.

Pocos años después, Kyra Galván establece una visión de México a lo largo de la historia en Netzabualcóyotl recorre las islas (1996), que inevitablemente tiene como parteaguas la conquista. El poema con título homónimo, y en el que se referencia a Cortés, se podría resumir a modo de ficción: Netzahualcóyotl despierta a finales del siglo XX y se desplaza en avión a Londres. Esa simple trama, entreverada con versos en inglés, pone en evidencia la extrañeza, la no aceptación del otro, para demostrar y denunciar las opresiones que han sufrido los mexicanos a lo largo de su historia, la vulneración continuada del ser mexicano, de la identidad y el infortunio de quien no va a encontrar su lugar:

Nunca más habrá lugar para nosotros.

Perdimos un mundo con todo y su cosmogonía

y nunca pudimos alcanzar otro.

Hablamos una lengua que nos prestaron.

Miren la vergüenza de los vencidos.

Cuántos siglos hemos cargado la culpa

de los conquistados, de los piel oscura.

Hay algo que no logramos alcanzar. (1996: 22)

Pues todavía "permanece / una armadura que nos asfixia / un corcel que nos pisotea, / un mastín que nos cercena" (1996: 22). Y se saca a colación también a los latinoamericanos imbuidos en trabajos de segunda y que no reconocen la grandeza del gran Netzahualcóyotl, y aquí entra la referencia de Cortés cuando "un portero portugués o colombiano" le comenta: "-Aquí, en el Museum of Mankind en Burlington Garden, / hay unas piezas del tesoro que mandó Cortés a Europa" (1996: 23). Sin saber que 
las penurias y desgracias del gran rey fueron sobrevenidas por el conquistador porque "ahí nadie sabe exactamente donde está México / ni les importa / porque en los Imperios no aprenden geografía" (1996: 23). Y el yo poético exhorta al gran rey: "Netza, netza, no te pierdas, no dejes / que la neblina de este país te devore", para añadir acto seguido: "No importa, me contesta, el shamán tenía razón. / Londres es como un ensueño, pero frío y oscuro. / ¡Ya puedo regresar a la luz!” (1996: 24).

La extensa composición de Kyra Galván marca un antes y un después en el tipo de discurso poético que adoptarán los jóvenes poetas respecto a su historia, al país, a la patria. La combinación del tiempo pasado — que se instaura en la horquilla del imperio azteca y la llegada de Cortés— con el presente será una constante en los versos que se escriban sobre poesía histórica, o bien patriótica. Como afirmó Alejandro Higashi, en la poesía mexicana de los autores nacidos a partir de los setenta existe una "incapacidad de reconocer una identidad nacional en el cauce tumultuoso de la globalización [...] si la poesía patriótica expresa el vínculo especial entre el sujeto y la identidad, la «desidentificación» estructural cancela el lazo de inmediato" (2017: 94-95).

Asimismo, la poesía de finales del siglo pasado y la del presente se instaura en un discurso marcadamente diferente al que se inscribió la poética de los años sesenta y setenta. Superados los tiempos de las utopías revolucionarias la poesía se ha revestido de un lenguaje en el que la parodia, la transgresión, la apropiación, la recontextualización de contenidos o el reciclaje se han convertido en los nuevos ejes que intervienen en el texto y ello afecta a la posición de lo histórico en la poesía y claramente a la presencia de Cortés entre los versos.

A modo de resumen, ofrecemos algunos autores que siguen esta nueva línea que se aleja de lo histórico propiamente dicho. En una línea similar a la encabezada por Kyra Galván, en el 2008, y de manera sucinta, Heriberto Yépez (1974) cita a Hernán Cortés en un verso en la segunda parte del "Canto del transmaíz", del libro El órgano de la risa (y otros diábolos). María Rivera (1971), en el poema "Desfile" (2010: 115-117), que formó parte de la antología País de sombra y fuego, incluye también la figura cortesiana. Hernán Bravo Varela (1979), por su parte, en el poema titulado "(De acuerdo con Google)" (2014: 112114), perteneciente al poemario Hasta aqui (2014), se centra en la figura de Cortés, con un juego que parte de su nombre propio, Hernán, y su presencia en internet. Alí Calderón (1982), en la segunda parte del poema "Democracia mexicana" (2015: 67-68), incluido en Las correspondencias (2015), utiliza un tipo de lenguaje, y fundamentalmente un tono, que recuerda a las Cartas de Relación de Hernán Cortés o a las crónicas de Bernal Díaz del Castillo en La historia verdadera de la Nueva España (García, 2017: 186-187); una forma de articular lo poético y lo histórico que ya se hizo presente en algún poema de su primer libro, Imago Prima (2005). Maricela Guerrero (1977), en Fricciones (2016), saca colación a nuestro personaje en algunos poemas a modo de deconstrucción.

La salvedad la marcaría Mario Calderón (1951), poeta perteneciente a una generación posterior a la de José Emilio Pacheco, quien publica en 2019 un libro en edición bilingüe titulado Leyendo el entorno en el que incluyen dos poemas que hacen referencia a la conquista y a Hernán Cortés, "Conquista del reino azteca" (2019: 72) y "Y avanza..." (2019: 76). Estos se completarían con el titulado "Hernán Cortés, conquistador del reino azteca" (2019a), que fue incluido en una antología publicada en la revista electrónica Círculo de poesía. Los dos primeros estarían, en líneas generales, en sintonía con la poética de Bonifaz Nuño, Pacheco y Aridjis; en el tercero de los citados el autor acude a referencias etimológicas. Si bien el poemario se ha publicado en fechas recientes, Calderón, como hemos señalado, pertenece a generaciones anteriores, con lo que su discurso poético no es lógicamente el de los más jóvenes y su visión de la historia en la poesía se encauza más — tal como acabamos de señalar — a la publicada en décadas anteriores, aunque lógicamente sin ser lo mismo.

Los acercamientos poéticos a la figura de Cortés han ido acompasados de las diversas formas de abordar lo poético en el siglo pasado; sin embargo, en México este personaje histórico sigue levantando 
resquemores, lo que lleva implícito — como hemos podido comprobar — una serie de aproximaciones cargadas - y precisamente por ello— de originalidad; una originalidad que se suma al quehacer de cada uno de los poetas. Sea como fuere, la sombra de Hernán Cortés sigue siendo alargada.

\section{Bibliografía}

Alemany BAy, Carmen (2004), "José Emilio Pacheco descubre una de sus máscaras para hablar del mundo precolombino y colonial", América sin Nombre, n. ${ }^{\circ}$ 5-6, pp. 5-11. DOI: $<$ https://doi.org/10.14198/AMESN2004.5-6.02>

Alemany Bay, Carmen (2017), "De los Comentarios reales del Inca Garcilaso a los Comentarios reales de Antonio Cisneros", Revista de crítica literaria latinoamericana. El Inca Garcilaso en dos orillas, n. XLIII (85), pp. 469482.

AÑÓN, Valeria (2008), “Antigüedades mexicanas: Memoria e intertextualidad en la poesía de José Emilio Pacheco", Orbis Tertius, n. $^{\circ}$ 13, $1-14$ :

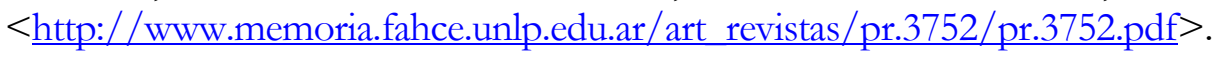

AridjIs, Homero (2002), Ojos de otro mirar. Poesía, 1960-2001. Ciudad de México, Fondo de Cultura Económica.

BONIFAZ NuÑo, Rubén (1986), Imagen de Tláloc: hipótesis iconográfica y textual. Ciudad de México, UNAM.

BONIFAZ NuÑo, Rubén (1988), “La descolonización de México”, Diálogo Nacional, 18, 12 de febrero, p. 25.

BONIFAZ NuÑo, Rubén (1996 [1979]), De otro modo lo mismo. Ciudad de México, Fondo de Cultura Económica.

Bravo VArela, Hernán (2014), Hasta aquí. Oaxaca (México), Editorial Almadía.

CALDERÓN, Alí (2005), Imago Prima. México, Universidad Autónoma de Zacatecas.

CALDERÓN, Alí (2015), Las correspondencias. Madrid, Visor Libros.

CALDERÓN, Mario (2019), Leyendo el entorno. Valparaíso, USA.

Calderón, Mario (2019a), "Hernán Cortés, conquistador del reino azteca", Círculo de poesía. $<$ https://circulodepoesia.com/2019/08/poesia-etimologica-una-poetica/ > .

Campos Marco, Antonio (2000), "El dueño de su lenguaje (entrevista de a Rubén Bonifaz Nuño)", La Jornada Semanal, 10 de agosto. <https://www.jornada.com.mx/2000/09/10/sem-campos.htm>.

GALVÁN, Kyra (1996), Netzabualcóyotl recorre las islas. México, Universidad Nacional Autónoma de México.

GARCía PRADOS, Nieves (2017), “Alí Calderón: La reconstrucción lírica de la historia de la cultura mexicana”, Nóesis. Revista de Ciencias Sociales y Humanidades, n. ${ }^{\circ}$ 26: 52, pp. 179-205. DOI: $<$ https://doi.org/10.20983/noesis.2017.2.8>.

GÓMEZ SORIANO, Miguel Ángel (2019), "La reescritura poética de la historia inca en El enemigo y la mañana de Jorge Enrique Adoum", Mitologias hoy, n. ${ }^{\circ}$ 19, pp. 257-73. DOI: $<$ https://doi.org/10.5565/rev/mitologias.621>.

Guerrero, Maricela (2016), Fricciones. México, Secretaría de Cultura / Centro de Cultura Digital.

Higashi, Alejandro (2017), "México, poesía y patria para el siglo XXI", iMex. México Interdisciplinario. Interdisciplinary Mexico, n. ${ }^{\circ}$ 11, pp. 88-102.

LEFERE, Robin (2014), La novela histórica: (re)definición, caracteriqación, tipología. Madrid, Visor.

PACHECO, José Emilio (2010), Tarde o temprano [poemas 1958-2009]. Barcelona, Tusquets editores. 
Rivera, María (2010), "Desfile”, País de sombra y fuego. Prólogo de José Emilio Pacheco. Selección y prefacio de Jorge Esquinca. Guadalajara, Maná/Selva Negra/Universidad de Guadalajara, pp. 115-117.

Salazar Anglada, Aníbal (prol. y ed.) (2018), Antología poética (1960-2018) de Homero Aridjis. Madrid, Cátedra.

Salazar Anglada, Aníbal (2019), "Juan Cabezón en tierras de América. Memorias del Nuevo Mundo de Homero Aridjis: génesis, antecedentes, proyecciones”, Nuevas de Indias. Anuario del CE $A C, \mathrm{n} .^{\circ} \mathrm{IV}$, pp. 112-162. DOI: < https://doi.org/10.5565/rev/nueind.43>.

SAlazAr AngladA, Aníbal (2020), "Poesía mexicana contemporánea: Diario de sueños (2011) o la madurez poética de Homero Aridjis", América sin nombre, n. ${ }^{\circ}$ 24, pp. 79-89. DOI: < https://doi.org/10.14198/AMESN.2020.24-2.07>.

SANCHIS AMAT, Víctor Manuel (2015), "La ciudad se quedó sola: recuperaciones de la historia mexicana en algunos poemas de José Emilio Pacheco y Homero Aridjis", Cuadernos del Hipogrifo, n. ${ }^{\circ} 3$, pp. 148-161.

YÉPEZ, Heriberto (2008), El órgano de la risa (y otros diábolos). México, Consejo Nacional para la Cultura y las Artes / Aldus. 